\title{
Variabel Fundamental Yang Mempengaruhi Struktur Keuangan Dan ImplikasinyaTerhadap Rentabilitas Ekonomi
}

\author{
Wiwiek Kusumaning Asmoro ${ }^{1 *}$, Novie Astuti Setianingsih ${ }^{2}$, Eti Putranti ${ }^{3}$ \\ Politeknik Negeri Malang PSDKU Kediri ${ }^{1,2,3}$ \\ wiwiek.kusumaning@polinema.ac.id ${ }^{1}$, viecoll77@gmail.com², eti.putranti@polinema.ac.id ${ }^{3}$
}

*Penulis Korespondensi

Diajukan : 30 Agustus 2021

Disetujui : 19 September 2021

Dipublikasikan : 6 Oktober 2021

\begin{abstract}
Fundamental variables in this research are shown in the level of sales growth, asset structure, company size and retained earnings. The purpose of this study was to determine the effect of sales growth rate, asset structure, firm size and retained earnings on financial structure. In addition, the purpose of this study is to examine how these variables affect economic rentability. The population in this study is the Food and Beverage Industry Sub-sector listed on the Indonesia Stock Exchange for the 2016-2020 period as many as 15 companies. The sampling technique is using purposive sampling which is a technique in sampling with certain considerations. The sampling technique is carried out proportionally sampling with the type of Judgment Sampling. Data collection technique used is documentation technique with polling data type. The number of samples in this study were 11 companies, the data used in the form of financial statements of the Food and Beverage Industry Subsector obtained from the Indonesia Stock Exchange. The results showed that sales growth and retained earnings had a positive effect on financial structure, while asset structure and firm size had a negative effect. The results of research on economic rentability, sales growth variables and retained earnings also have a positive effect, while asset structure and firm size have a negative effect. So the findings of this study can be concluded that the growth rate of sales, retained earnings can improve the financial structure and economic rentability of the company.
\end{abstract}

Keywords: Fundamental Variables, Financial Structure, Economic Rentability.

\section{PENDAHULUAN}

Masalah pembelanjaan merupakan aktivitas pemenuhan dan penggunaan dana. Pembelanjaan berarti mengadakan keseimbangan antara aktiva dan pasiva sebaik-baiknya.Untuk membiayai operasinya sehari-hari baik investasi dan kebutuhan lainnya setiap perusahaan membutuhkan dana. Pemenuhan kebutuhan dana dapat dari dalam perusahaan dan dari luar perusahaan. Struktur keuangan dapat diartikan bagaimana aktiva perusahaan dibelanjai. Dengan demikian struktur keuangan tercermin dalam keseluruhan pasiva dalam neraca. Menurut (Jogiyanto, 2010) struktur keuangan mencerminkan perimbangan baik dalam arti absolut maupun relatif antara keseluruhan modal asing (baik jangka pendek maupun jangka panjang dengan modal sendiri). Sehingga dalam membuat keputusan pendanan perusahaan harus memperhatikan dan menganalisis kombinasi sumber dana yang ekonomis untuk membelanjakan kebutuhan perusahaan.Disamping memperhatikan dan menganalisis kombinasi sumber dana, manajer keuangan juga harus memperhatikan variabel-variabel yang mempengaruhi keuangan. (Maskat, 2018)mengemukakan beberapa variabel yang mempengaruhi struktur keuangan perusahaan antara lain, tingkat pertumbuhan penjualan, stabilitas penjualan, struktur saingan, struktur aktiva, sikap manajemen dan sikap pemberi pinjaman.

Salah satu ukuran keberhasilan perusahaan dalam merealisasitujuannya adalah kemampulabaan. Kemampulabaan perusahaan dicerminkan dari perolehan laba atas hasil penjualan barang / jasa selama periode tertentu. Rentabilitas mempunyai 2 (dua) ukuran yaitu 
rentabilitas ekonomi dan rentabilitas modal sendiri. Rentabilitas Ekonomi (RE) kemampulabaan atas seluruh modal yang ditanamkan dalam perusahaan, sedangkan Rentabilitas Modal Sendiri (RMS) merupakan kemampulabaan atas modal sendiri yang ditanamkan.(Sagara et al., 2021).Dikarenakan begitu pentingnya penentuan kebutuhan pedanaan bagi kelangsungan hidup perusahaan, sehingga pembuatan keputusan pendanaan oleh manajer perlu memperhatikan variabel-variabel yang mempengaruhi struktur keuangan dan rentabilitas, hal tersebut akan dapat menentukan kebijakan pendanaan yang tepat dan dapat mengetahui efisiensi operasi perusahaan

Menurut(Purbandari \& Immanuela, 2018)bahwa variabel fundamental yang berpengaruh terhadap struktur keuangan, antara lain tingkat pertumbuhan penjualan, stuktur aktiva, stabilitas penjualan, ukuran perusahaan, stabilitas arus kas, sikap manajemen, sikap kreditur, beban pajak, kelas industri dan resiko perusahaan serta kebijakan deviden, namun pada penelitian ini peneliti membatasi 4 (empat) variabel yaitu mempengaruhi stuktur keuangan yaitu tingkat pertumbuhan penjualan, struktur asset, stabilitas penjualan, ukuran perusahaan, dan laba ditahan dan implementasinya pada rentabilitas ekonomi.Oleh sebab itu berdasarkan latar belakang permasalahan, maka dapat dirumuskan masalah pokok penelitian yaitu "Bagaimana Variabel Fundamental Yang Mempengaruhi Struktur Keuangan Dan ImplikasinyaTerhadap Rentabilitas Ekonomi (Studi Pada Perusahaan Food and Beverage Yang Listing Di BEI)". Penelitian dilakukan pada perusahaan makanan dan minuman karena perusahaan tersebut menghasilkan produk untuk kebutuhan primer, artinya dalam kondisi apapun makanan dan minuman selalu dibutuhkan dan tetap bertahan meski dalam kondisi krisis.

\section{Teori Faktor Fundamental}

\section{STUDI LITERATUR}

Informasi yang bersifat fundamental diperoleh dari kondisi intern perusahaan yang berupa data laporan keuangan perusahaan seperti: laba, dividen yang dibayar, penjualan dan lainlain.Faktor fundamental perusahaan memegang peranan penting dalam proses pengambilan keputusan(Jogiyanto, 2010). Faktor fundamentaljuga sebagai tolak ukur tingkat pertumbuhan penjualan, stuktur aktiva, stabilitas penjualan, ukuran perusahaan, stabilitas arus kas, sikap manajemen, sikap kreditur, beban pajak, kelas industri dan resiko perusahaan serta kebijakan deviden (Purbandari \& Immanuela, 2018). Dalam penelitian ini faktor fundamental di proksikan pada pertumbuhan penjualan, struktur aktiva (asset), ukuran penjualan dan laba ditahan.

\section{Teori Struktur Keuangan}

Manajemenkeuangan menyangkut aktivitas pemenuhan dan penggunaan dana dengan cara melakukan keseimbangan finansial di dalam perusahaan yakni melakukan keseimbangan antara aktiva dan pasiva yang dibutuhkan serta mencari susunan kualitatif dari aktiva dan pasiva tersebut dengan sebaik-baiknya. Pemilihan susunan kualitatif dari aktiva akan menentukan struktur kekayaan perusahaan, sedangkan pemilihan susunan kualitatif dari pasiva akan menentukan struktur finansial (struktur keuangan) dan struktur modalperusahaan (Safiuddin et al., 2015). Menurut (Sutrisno, 2017) Struktur keuangan dapat diartikan sebagai cara bagaimana asetperusahaan dibelanjai yang tercermin dalam keseluruhan pasiva dalam neraca. Berikut adalah perhitungan struktur keuangan yang hitung menggunakan rumus :

\begin{tabular}{|l|}
\hline Struktur keuangan $=\frac{\text { Total Hu tang }}{\text { Modal Sendiri }} \times 100 \%$ \\
\hline Sumber $:($ Sutrisno, 2017)
\end{tabular}

Sumber : (Sutrisno, 2017)

\section{Teori Rentabilitas Ekonomi}

Rentabilitas merupakan alat pengukur efesiensi perusahaan, masalah rentabilitas dipandang lebih penting daripada masalah laba. Sehingga yang perlu menjadi perhatian perusahaan adalah bagaimana mempertinggi rentabilitas, bukan mempertinggi laba. Karena laba yang besar belum tentu merupakan ukuran perusahaan dapat bekerja dengan efisien(Ilham, 2021).Rentabilitas 
menurut (Zlatevski, 2019) perbandingan antara laba denganaktiva atau modal yang menghasilkan laba. Penilaian efisiensi penggunaan modal \& aktiva dengan rentabilitas diukur melalui dua metode, yakni rentabilitas ekonomis dan rentabilitas modalsendiri. Menurut (Kasmir, 2015)Pengukuran rentabilitas ekonomis dengan perbandingan antara laba operasi dengan keseluruhan modal yang dimiliki perusahaan yakni modal sendiri dan modal asing. Kemudian pada rentabilitas usaha, pengukurannya dengan membandingkan laba setelah pajak dengan ekuitas perusahaan. Berikut adalah perhitungan dalam rentabilitas ekonomi :

$$
\mathbf{R E}=\frac{E B I T}{\text { Total Aset }}
$$

Sumber : (Kasmir, 2015)

\section{Teori Pengaruh Pertumbuhan Penjualan Terhadap Struktur Keuangan dan Rentabilitas Ekonomi}

Menurut (Sagara et al., 2021)rasio pertumbuhan merupakan rasio yang menggambarkan kemampuan perusahaan dalam mempertahankan posisi ekonominya di tengah pertumbuhan perekonomian dan sektor usahanya. Sales growth (SAG) merupakan indikator permintaan dan daya saing perusahaan suatu industri.

Laju pertumbuhan suatu perusahaan akan mempengaruhi kemampuan keuntungan dalam mendanai kegiatan-kegiatan pada masa yang akan datang. Keberhasilan investasi periode masa lalu dan dapat dijadikan sebagai prediksi pertumbuhan di masa yang akan datang.. (Kasmir, 2015). Untuk mengetahui seberapa besar tingkat pertumbuhan penjualan maka, dapat di hitung sebagai berikut :

$$
\begin{array}{|l|}
\hline \text { Growth of Sales }=\frac{\mathrm{s}_{1}-\mathrm{s}_{\mathrm{t}-1}}{\mathrm{~s}_{\mathrm{t}-1}} \times 100 \% \\
\hline \text { Sumber : (Kasmir, 2015) }
\end{array}
$$

Keterangan :

$\mathrm{S}_{1}$ : Penjualan pada tahun ke $\mathrm{t}$

$\mathrm{S}_{\mathrm{t}-1}$ : Penjualan pada periode sebelumnya

Berdasarkan penelitian terdahulu bahwa Perusahaan dengan tingkat penjualan lebih stabil dan cenderung meningkat dapat menggunakan hutang lebih besar pembiayaan (Trang et al., 2015),sedangkan (Sagara et al., 2021) yang menemukan bahwa pertumbuhan penjualan berpengaruh positif dan signifikan terhadap struktur keuangan. Sedangkan hasil penelitian (Ilham, 2021) perusahaan yang mempunyai tingkat pertumbuhan penjualan dan laba baik, akan mempunyai hutang tinggi sehingga berpengaruh pada rentabilitas ekonomi.Maka hipotesis yang diajukan adalah :

\section{$\mathrm{H}_{1}$ : Terdapat Pengaruh Pertumbuhan Penjualan Terhadap Struktur Keuangan $\mathrm{H}_{2}$ : Terdapat Pengaruh Pertumbuhan Penjualan Terhadap Rentabilitas Ekonomi}

\section{Teori Pengaruh Struktur Aktiva (Aset) Terhadap Struktur Keuangan dan Rentabilitas Ekonomi}

Menurut Sjahrial (2008) bahwa perusahaan yang memiliki aset tetapdalam jumlah besar dapat menggunakan hutang dalam jumlah besar hal ini disebabkan karena dari skalanya perusahaan besar lebih mudah mendapatkan akses ke sumber dana dibandingkan dengan perusahaan kecil. Kemudian besarnya aset tetap dapat digunakan sebagai jaminan atau kolateral hutang perusahaan. (Astuti, 2015). Strukturaset menggambarkan perbandingan antaratotalaset tetapdengan total aset perusahaan."Perbandingan antara jumlah aset tetap dengan jumlah aset adalah untuk 
mengalokasikan kas yang dikeluarkan untuk pendanaan operasional perusahaan agar terhindar dari resiko kebangkrutan (Sulindawati et.al., 2018). Berikut adalah perhitungan dalam struktur asset :

$$
\text { Struktur Aset }=\frac{\text { Aset Lancar }}{\text { AsetTetap }} \times 100 \%
$$

Sumber : (Sulindawati et.al., 2018)

Penelitian (Francis \& Boboye, 2020), yang menemukan bahwa Struktur Asset berpengaruh positif terhadap struktur keuangan perusahaan. Penelitian ini menemukan pengaruh negatip antara variabel Struktur Asset dengan struktur keuangan dikarenakan kondisi krisis yang masih parah, waktu penelitian dan obyek penelitian yang berbeda, sedangkan penelitian(Kartika, 2016) struktur aktiva tidak berpengaruh terhadap struktur keuangan perusahaan. Berbeda dengan penelitian bahwa perusahaan yang memiliki aktiva tetap akan cenderung menggunakan modal asing lebih besar sehingga meningkatkan rentabilitas ekonomi. Maka hipotesis yang diajukan adalah :

\section{$\mathrm{H}_{3}$ : Terdapat Pengaruh Struktur Aktiva (Aset) Terhadap Struktur Keuangan $\mathrm{H}_{4}$ : Terdapat Pengaruh Struktur Aktiva (Aset) Terhadap Rentabilitas Ekonomi}

\section{Teori Pengaruh Ukuran Perusahaan Terhadap Struktur Keuangan dan Rentabilitas Ekonomi}

Ukuran perusahaan dapat dinyatakan dalam total aset, penjualan, dan kapitalisasi pasar. Ukuran perusahaan (size) didefinisikan sebagai logaritma natural dari total aset diharapkan memiliki pengaruh positif pada pembayaran dividen karena perusahaan besar yang lebih terdiversifikasi kemungkinan memiliki peluang kebangkrutan yang sangat rendah dan dapat mempertahankan tingkat utang yang lebih tinggi.(Ahmad \& Wardani, 2014).Ukuran perusahaan merupakan besarnya asset yang dimiliki perusahaan. Ukuran perusahaan diukurdengan menggunakan logaritma natural dari nilai buku aktiva(Jogiyanto, 2010) :

\section{Size $=$ Log Natural $($ Ln) Total Aset}

Sumber: (Jogiyanto, 2010)

Ukuran perusahaan dijadikan pengukuran dalam menentukan keberhasilan suatu perusahaan. Semakin tinggi nilai ukuran perusahaan maka kinerja keuangan akan semakin baik. Hal ini sesuai dengan penelitian yang dilakukan oleh (Antikasari et al., 2020), sedangkan (Francis \& Boboye, 2020)yang menemukan bahwa ukuran perusahaan berpengaruh positip dan signifikan terhadap struktur keuangan. semakin besar ukuran perusahaan, akan semakin tinggi / besar penggunaan modal asing. Sehingga akan menaikkan rentabilitas ekonomi perusahaan.(Trang et al., 2015). Hipotesis yang diajukan adalah :

\section{$H_{5}$ : Terdapat Pengaruh Ukuran Perusahaan Terhadap Struktur Keuangan H$_{6}$ : Terdapat Pengaruh Ukuran Perusahaan Terhadap Rentabilitas Ekonomi}

\section{Teori Pengaruh Laba Ditahan Terhadap Struktur Keuangan dan Rentabilitas Ekonomi}

Laba ditahan (retained earnings) merupakan laba yang tidakdibagikan kepada pemegang saham, tetapi laba yang ditanamkan kembali kedalam perusahaan tidak semua dibagikan kepada pemegang sahamsebagai dividen tetapi sebagai salah satu sumber dana yang paling penting untuk membiayaipertumbuhan perusahaan.Perusahaan yang mempunyai sumber dana intern yang tinggi, dapatmembuat manejer untuk menggunakan dana dalam kegiatan perusahaan sehingga akan meningkatkan harga saham perusahaan. (Sulindawati et.al., 2018). Berikut perhitungan dalam laba ditahan : 


\section{Laba ditahan = Laba bersih setelah pajak - dividen}

Sumber : (Sulindawati et.al., 2018)

Penelitian terdahulu (Astuti, 2015) dan (Atidhira \& Yustina, 2017) bahwa laba ditahan berpengaruh negatif dan signifikan terhadap struktur keuangan sedangkan laba ditahan berpengaruh positif signifikan terhadap rentabilitas ekonomi sehingga laba ditahan makin tinggi akan menurunkan penggunaan modal asing dan memperkecil rentabilitas ekonomi. (Halim et al., 2015). Maka hipotesis yang diajukan adalah :

\section{$\mathrm{H}_{7}$ : Terdapat Pengaruh Laba Ditahan Terhadap Struktur Keuangan $\mathrm{H}_{8}$ : Terdapat Pengaruh Laba Ditahan Terhadap Rentabilitas Ekonomi}

\section{METODE}

Penelitian ini menggunakan pendekatan kuantitatif. Menurut (Sugiyono, 2018)menjelaskan bahwa, penelitian kuantitatif merupakan metode penelitian yang berlandaskan pada filsafat positivisme, digunakan untuk meneliti pada populasi atau sampel tertentu. Metode penelitian yang digunakan adalah metodedeskrtiptif.Menurut (Sujarweni, 2015)metode deskriptifadalah penelitian yang dilakukan untuk mengetahui nilai masing-masing variabel, baik satu variabel atau lebih sifatnya independen tanpa membuat hubungan maupun perbandingan dengan variabel yang lain.Jenis data yang digunakan adalah data sekunder. Data sekunder adalah data yang sudah tersedia dan dikumpulkan oleh pihak lain. Data sekunder dalam penelitian ini yaitu data yang diperoleh secara tidak langsung yang dipublikasikan oleh Bursa Efek Indonesia. melalui situs IDX Bursa Efek Indonesia, laporan keuangan subsektor Food and Beverage di Bursa Efek Indonesia Pada Periode 2016-2020 dan juga jurnal penelitian serta buku-buku referensi yang berkaitan dengan judul penelitian.

\section{Populasi dan Sampel}

Populasi pada penelitian ini Subsektor IndustriFood and Beverage yang terdaftar di BEI periode 2016-2020 sebanyak 15 perusahaan. Teknik penarikan sampel dengan menggunakan purposive sampling yang merupakan satu teknik dalam pengambilan sampel dengan beberapa pertimbangan tertentu (Sugiyono, 2018).

Tabel 1. Kriteria Pengambilan Sampel Penelitian

\begin{tabular}{|c|l|c|}
\hline No. & \multicolumn{1}{|c|}{ Kriteria } & Jumlah Sampel \\
\hline 1 & $\begin{array}{l}\text { Perusahaan Sub Sektor Industri Food and Beverage yang } \\
\text { terdaftar di Bursa Efek Indonesia Periode 2016-2020 }\end{array}$ & 15 \\
\hline 2 & $\begin{array}{l}\text { Perusahaan Sub Sektor Industri Food and Beverage } \\
\text { yang mempublikasikan laporan keuangan secara berturut } \\
\text { selama Periode 2016 -2020 }\end{array}$ & 15 \\
\hline & $\begin{array}{l}\text { Perusahaan Sub Sektor Industri Food and Beverage yang } \\
\text { memiliki laba selama periode 2016-2020 }\end{array}$ & 11 \\
\hline Jumlah Perusahaan Yang Menjadi Sampel Penelitian & 55 \\
\hline \multicolumn{2}{|l|}{ Data Observasi Penelitian 11 x 5 }
\end{tabular}

Sumber : Hasil Penelitian, 2021 (Data Diolah)

\section{Identifikasi Variabel Penelitian dan Definisi Operasional Variabel}

1. Identifikasi veriabel penelitian

Dalam penelitian ini variabel terikat atau dependent variabelnya (Y) adalah:

$\mathrm{Y}_{1}=$ struktur keuangan dan 
Owner: Riset \& Jurnal Akuntansi

e-ISSN : 2548-9224 |p-ISSN : 2548-7507

Volume 5 Nomor 2, Agustus 2021

DOI : https://doi.org/10.33395/owner.v5i2.514

Y2 = rentabillitas ekonomi

Variabel bebas merupakan variabel fundamental yaitu (Independent variabel ) $=\mathrm{X}$, yang di proksikan sebagai berikut :

$\mathrm{X}_{1}=$ Tingkat Pertumbuhan penjualan

$\mathrm{X}_{2}=$ Struktur Asset

$\mathrm{X}_{3}=$ Ukuran Perusahaan

$\mathrm{X}_{4}=$ Laba ditahan

2. Definisi Operational Variabel

- Variabel terikat

Struktur keuangan adalah merupakan perbandingan total hutang dengan modal sendiri

Struktur keuangan $=\frac{\text { Total Hu tang }}{\text { Modal Sendiri }} \times 100 \%$

Rentabilitas Ekonomi (Y2) kemampuan perusahaan untuk menghasilkan keuntungan dengan modal yang dimiliki.

$\boldsymbol{R E}=\frac{E B I T}{\text { Total Aset }}$

- Variabel Bebas.

a. Tingkat pertumbuhan penjualan (X1) yaitu perbandingan antara penjualan tahun yang bersangkutan dengan penjualan tahun sebelumnya

Growth of Sales $=\frac{\mathrm{s}_{1}-\mathrm{s}_{\mathrm{t}-1}}{\mathrm{~s}_{\mathrm{t}-1}} \times 100 \%$

b. Struktur Asset $\left(\mathrm{X}_{2}\right)$ adalah perbandingan antara aset lancar dengan aset tetap.

Struktur Aset $=\frac{\text { Aset Lancar }}{\text { AsetTetap }} \times 100 \%$

c. Ukuran perusahaan $\left(\mathrm{X}_{3}\right)$ dengan melihat total aktiva perusahaan tiap periodenya.

Size $=$ Log Natural (Ln) Total Asset

d. Laba ditahan $\left(\mathrm{X}_{4}\right)$ adalah sebagian dari laba / keuntungan yang tidak dibagi kepada pemegang saham, yaitu merupakan akumulasi laba ditahan pada periode penelitian tahun 2016 sampai tahun 2020.

\section{Laba ditahan = Laba bersih setelah pajak - dividen}

\section{HASIL}

Sampel pada penelitian ini sebanyak 11 perusahaan dengan periode penelitian dari 2016-2020 sehingga diperoleh data sejumlah 55 data penelitian. Hasil pengolahan data menggunakan software SPSS versi 14.00.dapat dilihat pada uji statistik berikut :

Analisa Regresi Variabel $\mathbf{X}$ terhadap $\mathbf{Y}_{1}$

Dalam penelitian ini meggunakn software SPSS versi 14.00. Hasil analisis regresi variabel $\mathrm{X}$ terhadap $\mathrm{Y}_{1}$ adalah : 
Tabel 2. Hasil Regresi Variabel-variabel X terhadap Variabel $\mathrm{Y}_{1}$

\begin{tabular}{lrc}
\hline \multicolumn{1}{c}{ Variabel } & B & Sig t \\
\hline Konstanta & 5,248 & 0,023 \\
X $_{1}$ (Pertumbuhan penjualan) & 0,031 & 0,789 \\
X $_{2}$ (Struktur Asset ) & $-0,287$ & 0,013 \\
X $_{3}$ (Ukuran Perusahaan) & $-0,016$ & 0,883 \\
X $_{4}$ (Laba Ditahan) & 0,592 & 0,000 \\
\hline F Sig = 0,000 & & \\
Adjusted R Square $=0,271$ & & \\
\hline Sumber : Hasil Penelitian, 2021 (Data Diolah) & &
\end{tabular}

Berdasarkan tabel diatas, model analisis regresi berganda antara variabel $\mathrm{X}$ terhedap variabel $\mathrm{Y}_{1}$ dapat dirumuskan dalam bentuk persamaan sebagai berikut :

$\mathrm{Y}_{1}=5,248+0,031 \mathrm{X}_{1}+-0,287 \mathrm{X}_{2}+-0,16 \mathrm{X}_{3}+0,592 \mathrm{X}_{4}$

Dari hasil persamaan regresi berganda tersebut masing-masing variabel dapat diinterprestasikan pengaruhnya terhadap struktur keuangan yaitu:

1. Pertumbuhan penjualan $\left(\mathrm{X}_{1}\right)$.

Pertumbuhan penjualan memiliki koefisien regresi positif sebesar 0,031 yang berarti apabila nilai koefisien regresi lainnya konstan, maka perubahan penjualan 1 akan menyebabkan struktur keuangan meningkat 0,031, hal ini sesuai dengan teori yang dikemukakan (Weston dan Bringham ,2010) bahwa variabel yang mempengaruhi struktur keuangan adalah pertumbuhan penjualan. Jika penjualan meningkat, maka kemungkinan besar laba juga akan meningkat, dengan meningkatnya pertumbuhan penjualan maka pembiayaan dengan hutang dengan beban tetap akan meningkatkan pendapatan pemilik saham dan juga akan membantu pembiayaan modal. Perusahaan dengan tingkat penjualan lebih stabil dan cenderung meningkat dapat menggunakan hutang lebih besar pembiayaan(Trang et al., 2015),sedangkan (Astuti, 2015) dan (Sagara et al., 2021) yang menemukan bahwa pertumbuhan penjualan berpengaruh positif dan signifikan terhadap struktur keuangan. Jadi perusahaan yang memiliki tingkat pertumbuhan penjualan dan profitabilitas yang meningkat akan menggunakan hutang lebih besar karena akan meningkatkan rentabilitas perusahaan.

\section{Struktur Asset $\left(\mathrm{X}_{2}\right)$.}

Struktur Assetmemiliki koefisien regresi bertanda negatif sebesar 0,287, hal ini mengandung makna bahwa apabila nilai koefisien regresi variabel lainnya tetap (tidak berubah) maka perubahan Struktur Asset1 akan menurunkan struktur keuangan sebesar 0,287. Hal ini tidak sesuai dengan teori yang dikemukakan oleh (Sulindawati,2019) bahwa perusahaan yang memiliki aktiva tetap sebagai anggunan hutang cenderung akan menggunakan modal asing yang lebih besar. Hasil penelitian ini juga tidak mendukung penelitian terdahulu (Francis \& Boboye, 2020), yang menemukan bahwa Struktur Assetberpengaruh positip terhadap struktur keuangan perusahaan.Penelitian ini menemukan pengaruh negatip antara variabel Struktur Asset dengan struktur keuangan dikarenakan kondisi krisis yang masih parah, waktu penelitian dan obyek penelitian yang berbeda.

\section{Ukuran Perusahaan $\left(\mathrm{X}_{3}\right)$}

Ukuran perusahaan memiliki koefisien regresi negatif sebesar -0,016 yang artinya jika nilai koefisien regresi lainnya tetap, maka perubahan ukuran perusahaan sebesar satu akan menyebabkan penurunan struktur keuangan sebesar 0,016 . Hal ini tidak mendukung teori yang dikemukakan teori (Weston dan Bringham, 2010).Penelitian (Francis \& Boboye, 2020), dan (Trang et al., 2015) yang menemukan bahwa ukuran perusahaan berpengaruh positip dan signifikan terhadap struktur keuangan. Hasil penelitian yang tidak mendukung teori dan penelitian terdahulu disebabkan berbagai hal, antara lain waktu penelitian, obyek penelitian, tempat / kondisi negara yang berbeda. Pada periode tahun 2016-2020 kondisi perekonomian 
masih dalam kondisi krisis yang belum mampu naik pada masa pemulihan ekonomi.Dari uraian dapat disimpulkan bahwa ukuran perusahaan mempunyai pengaruh negatif terhadap struktur keuangan.

\section{Laba Ditahan $\left(\mathrm{X}_{4}\right)$}

Laba ditahan mempunyai koefisien regresi positif sebesar 0,592 yang artinya jika nilai koefisien regresi variabel lainnya tetap, maka perubahan variabel laba ditahan sebesar 1 akan menyebabkan peningkatan struktur keuangan sebesar 0,592. Hasil penelitian ini tidak sesuai dengan teori yang ada, bahwa jika perusahaan memilih menahan laba (laba ditahan) maka akan membentuk dana intern lebih besar (Sulindawati,2018). Berbeda dengan penelitian terdahulu (Astuti, 2015) dan (Atidhira \& Yustina, 2017)bahwa laba ditahan berpengaruh negatif dan signifikan terhadap struktur keuangan.

\section{Analisa Regresi Variabel X dan Y1 terhadap Y2}

Setelah melihat hasil regresi variabel $\mathrm{X}$ terhadap variabel $\mathrm{Y} 1$, selanjutnya melihat hasil analisis regresi variabel $\mathrm{X}$ terhadap $\mathrm{Y} 2$. Hasil analisis regresi tersebut dapat dilihat pada tabel berikut ini :

Tabel . Hasil regresi variabel $\mathrm{X}$ terhadap $\mathrm{Y}_{2}$

\begin{tabular}{lcc}
\hline \multicolumn{1}{c}{ Variabel } & $\mathrm{B}$ & Sig t \\
\hline Konstanta & 1.362 & 0,113 \\
X $_{1}$ (Pertumbuhan penjualan) & 0,032 & 0,688 \\
$\mathrm{X}_{2}$ (Struktur Asset ) & $-0,018$ & 0,817 \\
$\mathrm{X}_{3}$ (Ukuran Perusahaan) & $-0,070$ & 0,366 \\
$\mathrm{X}_{4}$ (Laba Ditahan) & 0,831 & 0,000 \\
\hline
\end{tabular}

F Sig : 0,000

Adjusted R Square 647

Sumber: Hasil Penelitian, 2021 (Data Diolah)

Dari hasil regresi pada tabel di atas, maka model analisis regresi berganda antara variabel $\mathrm{X}$ terhadap $\mathrm{Y}_{2}$ dapat dirumuskan dalam bentuk persamaan sebagai berikut :

$Y_{2}=1,362+0,032 X_{1}+-0,018 X_{2}+-0,070 X_{3}+0,831 X_{4}$

Hasil persamaan regresi berganda tersebut, masing-masing variabel dapat diinterpretasikan pengaruhnya terhadap rentabilitas ekonomi yaitu:

1. Pertumbuhan Penjualan

Pertumbuhan penjualan memiliki koefisien regresi positip sebesar 0,032 yang berarti apabila nilai koefisien regresi variabel lainnya tetap, maka perubahan variabel pertumbuhan penjualan sebesar 1 akan menyebabkan kenaikan rentabilitas ekonomi sebesar 0,032 jika penjualan ini meningkat berarti kemungkinan besar laba meningkat dengan meningkatnya pertumbuhan penjualan, maka pembiayaan dengan hutang dengan beban tetap tertentu akan meningkatkan rentabilitas ekonomi perusahaan. Hasil penelitian ini relevan dengan penelitian sebelumnya.(Ilham, 2021) Perusahaan yang mempunyai tingkat pertumbuhan penjualan dan laba baik, akan mempunyai hutang tinggi sehingga berpengaruh pada rentabilitas ekonomi.

2. Struktur Asset

Struktur Asset memiliki koefisien regresi bertanda negatip sebesar -0,018. Hal ini mengandung makna bahwa apabila nilai koefisien regresi variabel lainnya tetap (tak berubah) maka perubahan variabel Struktur Assetsebesar 1 akan menurunkan rentabilitas ekonomi sebesar 0,018 .

Penelitian ini bertentangan (tidak mendukung) penelitian terdahulu bahwa perusahaan yang memiliki aktiva tetap akan cenderung menggunakan modal asing lebih besar sehingga meningkatkan rentabilitas ekonomi.(Dinata et al., 2015)

3. Ukuran Perusahaan 
Ukuran perusahaan memiliki koefisien regresi negatip sebesar -0,070. Hal ini mengandung makna bahwa apabila nilai koefisien regresi variabel lain konstan, maka perubahan variabel ukuran perusahaan 1 akan menurunkan rentabilitas $-0,070$. Penelitian ini tidak mendukung penelitian terdahulu,karena semakin besar ukuran perusahaan, akan semakin tinggi / besar penggunaan modal asing. Sehingga akan menaikkan rentabilitas ekonomi perusahaan.(Trang et al., 2015)

4. Laba Ditahan

Laba ditahan mempunyai koefisien regresi bertanda positip sebesar 0,831 . Hal ini bermakna bahwa apabila nilai koefisien regresi variabel yang lain tetap (tidak berubah) maka perubahan laba ditahan sebesar 1 akan meningkatkan rentabilitas ekonomi sebesar 0,831 . Hal ini tidak mendukung penelitian terdahulu (Halim et al., 2015) Bahwa laba ditahan makin tinggi akan menurunkan penggunaan modal asing dan memperkecil rentabilitas ekonomi.

\section{Struktur Keuangan}

\section{PEMBAHASAN}

a. Pengaruh Pertumbuhan Penjualan terhadap Struktur Keuangan

Pertumbuhan penjualan berpengaruh signifikan positif berarti perubahan pertumbuhan penjualan akan diikuti searah dan secara nyata terhadap struktur keuangan. Dalam upaya mencapai penjualan tertentu dibutuhkan total aktiva yang diimbangi dengan peningkatan struktur keuangan. Karena itu diharapkan perusahaan mempertimbangkan keuntungan menggunakan hutang.

b. Pengaruh Struktur Asset terhadap Struktur Keuangan

Struktur Asset berpengaruh signifikan negatif, berarti perubahan Struktur Asset tidak searah dan secara nyata terhadap struktur keuangan. Sehingga perusahaan dalam kondisi krisis ini tidak meningkatkan aktiva tetapnya dan tidak optimal dalam memanfaatkan kapasitas produksinya.

\section{c. Pengaruh Ukuran Perusahaan terhadap Struktur Keuangan}

Ukuran perusahaan berpengaruh signifikan negatif yang berarti perubahan-perubahan ukuran perusahaan tidak searah dengan struktur keuangan. Pada periode tahun 2016 sampai dengan 2020 perubahan (pertumbuhan penjualan berfluktuasi naik turun / tidak stabil) sehingga tidak mengakibatkan pembiayaan modal asing.

\section{d. Pengaruh Laba Ditahan terhadap Struktur Keuangan}

Laba ditahan berpengaruh positip berarti perubahan laba ditahan searah dan secara nyata terhadap struktur keuangan. Perusahaan perlu mengarahkan perhatiannya pada kebijakan pembayaran dividen. Dimana kebijakan dividen harus tepat dan disesuaikan keinginan para pemegang saham.

\section{Rentabilitas Ekonomi}

a. Pengaruh Pertumbuhan Penjualan terhadap Rentabilitas Ekonomi

Pertumbuhan penjualan berpengaruh signifikan positif pada rentabilitas ekonomi. Pertumbuhan penjualan akan meningkatkan hutang sehingga dapat meningkatkan rentabilitas ekonomi. Sehingga perusahaan harus mencari dana yang memiliki biaya rendah.

\section{b. Pengaruh Struktur Asset terhadap Rentabilitas Ekonomi}

Struktur Asset berpengaruh signifikan negatif yang berarti perubahan Struktur Asset tidak searah dan nyata terhadap rentabilitas ekonomi. Dalam kondisi krisis perusahaan peningkatan volume penjualan tidak dapat dicapai dengan peningkatan asset tetap untuk memaksimalkan kapasitas produksi. 


\section{c. Pengaruh Ukuran perusahaan aktiva terhadap Rentabilitas Ekonomi}

Ukuran perusahaan berpengaruh signifikan negatif yang berarti perubahan ukuran perusahaan akan diikuti dengan perubahan searah dan senyata-nyata terhadap rentabilitas keuangan. Peningkatan aset tidak mampu meningkatkan hutang sehingga perusahaan harus meningkatkan volume penjualannya.

\section{d. Pengaruh Laba ditahan terhadap Rentabilitas Ekonomi}

Laba ditahan berpengaruh signifikan positif berarti perubahan laba ditahan searah dan secara nyata terhadap rentabilitas ekonomi. Sehingga perusahaan harus memperhatikan kebijakan dividen atau membagi laba sehingga dapat memperbesar hutang dan memperbesar rentabilitas ekonomi.

\section{KESIMPULAN}

Hasil penelitian untuk analisis regresi pada persamaan pertama terlihat bahwa variabel pertumbuhan penjualan dan laba ditahan bertanda positif terhadap struktur keuangan, hal ini berarti apabila variabel di atas ditingkatkan penggunaan modal asing yang lebih besar akan lebih baik karena akan meningkatkan rentabilitas ekonomi (laba yang lebih besar) apalagi jika tingkat bunga lebih rendah dari tingkat pengembalian investasi. Sedangkan variabel yang bertanda negatif maka struktur keuangan akan rendah karena cenderung menggunakan sumber dana intern.Pada persamaan kedua terlihat tingkat pertumbuhan penjualan, laba ditahan bertandapositif apabila ditingkatkan akan meningkat rentabilitas ekonomi.Dalam kondisi perekonomian yang baik akan menghasilkan rentabilitas ekonomi yang lebih besar dari biaya hutang, maka perusahaan mendanai asetnya dengan sebagian modal asing.Dalam kondisi perekonomian yang menurun, atau krisis akan menghasilkan rentabilitas ekonomi yang lebih kecil dari biaya hutang, maka perusahaan tidak mendanai asetnya dengan sebagian besar modal asing.

\section{REFERENSI}

Ahmad, G. N., \& Wardani, V. K. (2014). The Effect of Fundamental Factor To Dividend Policy: Evidence in Indonesia Stock Exchange. International Journal of Business and Commerce, $4(2), 14-25$.

Antikasari, L. D., Fajri, R. N., \& Dewi, R. R. (2020). Determinan Kinerja Keuangan Yang Ditinjau Dari Good Corporate Governance, Leverage dan Ukuran Perusahaan (Sub. Sector Perusahaan BUMN yang Terdaftar Di BEI tahun 2013-2018). Owner (Riset Dan Jurnal Akuntansi), 4(2), 336. https://doi.org/10.33395/owner.v4i2.208

Astuti, N. (2015). Pengaruh Struktur Asset, Pertumbuhan Penjualan, Ukuran Perusahaan,Profitabilitas, Resiko Bisnis, Deviden dan Degree of Operating Leverage Terhadap Struktur Keuangan. Media Bisnis, 7(1), 1-7.

Atidhira, A. T., \& Yustina, A. I. (2017). The Influence of Return on Asset, Debt to Equity Ratio, Earnings per Share, and Company Size on Share Return in Property and Real Estate Companies. JAAF (Journal of Applied Accounting and Finance), 1(2), 128-146. http://ejournal.president.ac.id/presunivojs/index.php/JAAF/article/download/363/207

Dinata, P. A. P. S., Sinarwati, N. K., \& Purnamawati, I. G. A. (2015). Analisis Pengaruh Pemberian Kredit, Kredit Bermasalah, Perputaran Kas, Volume Penjualan, Profit Margin Dan Struktur Finansial Terhadap Rentabilitas Ekonomi Pada Lembaga Perkreditan Desa (Lpd) Di Kecamatan Tejakula Periode 2010-2013. E-Journal S1 Ak Universitas Pendidikan Ganesha, 3(1).

Francis, B., \& Boboye, L. (2020). Financial Structure and Financial Performance of Listed Multinational Oil Companies. Journal of Management Sciences, 1(1), 135-146.

Halim, E., Efni, Y., \& Sari, M. (2015). Analisis Pengaruh Kebijakan Pendanaan Dan Laba Ditahan Terhadap Nilai Perusahaan Dengan Set Kesempatan Investasi Sebagai Variabel Mediasi (Studi Pada Perusahaan Lq-45 Yang Terdaftar Di Bei Periode 2009-2013). Jurnal Online Mahasiswa Fakultas Ekonomi Universitas Riau, 2(1), 33739.

Ilham, nurhayati. (2021). Analisis modal kerja terhadap rentabilitas ekonomi Analysis of working capital on economic profitability. 18(2), 178-183. 
Jogiyanto, H. (2010). Teori Portofolio dan Analisis Investasi (Ketujuh (ed.)). BPFE Yogyakarta.

Kartika, A. (2016). Pengaruh profitabilitas, struktur aset, pertumbuhan penjualan dan ukuran perusahaan terhadap struktur modal perusahaan manufaktur di Bursa Efek Indonesia. Jurnal Infokam, 1(1), 49-58. http://amikjtc.com/jurnal/index.php/jurnal/article/view/99

Kasmir. (2015). Analisis Laporan Keuangan (Edisi Pert). Rajawali Pers. Jakarta.

Maskat, F. M. (2018). Pengaruh Variabel Fundamental Terhadap Harga Saham Perusahaan Go Public di Bursa Efek Indonesia. Jurnal Ilmu Dan Riset Akuntansi, Volume 7,. http://jurnalmahasiswa.stiesia.ac.id/index.php/jira/article/view/94/92

Purbandari, T., \& Immanuela, I. (2018). Analisis Faktor Fundamental Terhadap Manajemen Laba Pada Perusahaan Yang Listed Di Bursa Efek Indonesia. Jurnal AKSI (Akuntansi Dan Sistem Informasi), 2(1), 56-63. https://doi.org/10.32486/aksi.v2i1.217

Safiuddin, M., Mohhedul-Islam, M., \& Anisuzzaman, M. (2015). Impact of financial structure on firm 's performance: A study on financial and nonfinancial sector in Bangladash. European Journal of Business and Management, 7(3), 30-39. www.iiste.org

Sagara, Y., Asmoro, W. K., Kembauw, E., \& Salikhovich, N. (2021). The Strategic Role of MSME Challenges in the Covid-19 Situation. Annals of the Romanian Society for Cell Biology Journal, 25(4), 4833-4843. https://www.annalsofrscb.ro/index.php/journal/article/view/3038

Sugiyono. (2017). Metode Penelitian Kuantitatif, Kualitatif, dan R\&D. Bandung Alfabeta CV.

Sujarweni, W. (2015). Metodologi Penelitian Bisnis Ekonomi. yogyakarta Pustaka Baru.

Sulindawati, D. (2018). Manajemen Keuangan Sebagai Dasar Pengambilan Keputusan Bisnis (Cetakan Ke). Rajawali Pers. Jakarta.

Sutrisno. (2017). Manajemen Keuangan Teori Konsep dan Aplikasi (Edisi Revi). Jakarta. Ekonesia.

Trang, I., Murni, S., \& Pantow, M. S. (2015). Analisa Pertumbuhan Penjualan, Ukuran Perusahaan, Return on Asset, Dan Struktur Modal Terhadap Nilai Perusahaan Yang Tercatat Di Indeks Lq 45. Jurnal Riset Ekonomi, Manajemen, Bisnis Dan Akuntansi, 3(1), 961-971. https://doi.org/10.35794/emba.v3i1.7801

Zlatevski, L. (2019). ECONOMY AND RENTABILITY OF MODERN COMPANIES. KNOWLEDGE - International Journal, 30, 121-124. 